\title{
UMA PEQUENA HISTÓRIA DO ESPAÇO (E DO TEMPO) o conceito de espaso em Kant, Lessing, Foucault e Benjamin
}

Georg Otte

UFMG

\begin{abstract}
RES U M O
O presente trabalho visa mostrar que tempo e espaço não são apenas "formas de intuição" (Kant), fundamentais na percepção dos objetos, mas que as duas categorias possuem um valor diferenciado nas "epistémes" (Foucault) de cada época. Nossa hipótese é que a temporalização do pensamento, que marca a passagem da "Idade Clássica" para a Modernidade, encontra em Walter Benjamin um dos seus mais expressivos adversários mediante a valorização do espaço.
\end{abstract}

\section{PALA VRAS - CHAVE}

Espaço. Estética. História. Walter Benjamin.

\section{KANT}

$\mathbf{P}_{\text {or mais que se conteste a tradicional separação entre matéria e forma, não há }}$ como negar que o sujeito, diante de uma grande diversidade de impressões, discerne e identifica determinados objetos como tais, ou seja, distingue sua forma. Filosoficamente, tal identificação passou por várias abordagens, como a anamnese do idealismo platônico, segundo a qual esta consiste em lembrar a idéia original do objeto, considerando este, por sua vez, como "simulacro" dessa idéia. Para Kant, que inaugura o Idealismo alemão, há também o a priori "ideal", sendo que o lugar da idéia não é mais a esfera divina, mas a humana; ela é subjetiva, no sentido de ser comum a todos os sujeitos. Kant denomina sua própria filosofia de "transcendental", uma vez que o a priori subjetivo transcende a matéria:

Dou o nome de matéria ao que no fenómeno corresponde à sensação; ao que, porém, possibilita que o diverso do fenómeno possa ser ordenado segundo determinadas relações, dou o nome de forma do fenómeno. Uma vez que aquilo, no qual as sensações unicamente se podem ordenar e adquirir determinada forma, não pode, por sua vez, ser sensação, segue-se que, se a matéria de todos os fenómenos nos é dada somente a posteriori, a sua forma deve encontrar-se a priori no espírito, pronta a aplicar-se a ela e portanto tem que poder ser considerada independentemente de qualquer sensação. ${ }^{1}$

\footnotetext{
${ }^{1}$ KANT. Crítica da razão pura, p. 62.
} 
Essa independência de "qualquer sensação" e a decorrente distinção entre matéria e forma foram questionadas ainda no próprio Idealismo alemão e pela subseqüente filosofia do Romantismo, e não faltam comentadores que detectam, principalmente nas publicações póstumas de Kant, traços de um materialismo latente.

Não se trata, no entanto, de discutir aqui a questão dessa independência postulada por Kant para substituí-la por uma possível interdependência, dialética ou não, entre matéria e forma. O parágrafo acima citado faz parte das reflexões em torno do tempo e do espaço, que, para o nosso filósofo, representam, respectivamente, "a forma pura das intuições (Anschauungen) sensíveis". ${ }^{2}$ No que diz respeito ao espaço, Kant constata que não nos é possível vê-lo, mas apenas objetos ou corpos no espaço. O espaço é um a priori, uma predisposição do sujeito que lhe permite ordenar os objetos da realidade externa, "a condição de possibilidade dos fenômenos, não uma determinação que dependa deles." Podemos imaginar um espaço sem objetos, mas não objetos sem espaço.

As considerações kantianas sobre tempo e espaço, reunidas no capítulo "Estética transcendental", ocupam uma parte relativamente pequena da Crítica da razão pura, dedicada à Teoria do conhecimento. Numa nota de rodapé, Kant faz questão de frisar que está fazendo uso do termo "estética" em um sentido próximo da origem grega de aisthesis, ou seja, tempo e espaço determinam a percepção da realidade enquanto estágio preliminar no desenvolvimento de conceitos. Não se trata da tentativa, empreendida por Baumgarten, de "submeter a princípios racionais o julgamento crítico do belo, elevando as suas regras à dignidade de uma ciência". ${ }^{4}$

De certa maneira, Kant supera a postura predominante no Renascimento e no Iluminismo de desenvolver estéticas e poéticas baseadas em "princípios racionais", assim como ele supera o racionalismo iluminista como um todo. "Crítica", para Kant, significa sondar os limites da razão ou então "as condições de possibilidade" das nossas faculdades. Apesar de sua fidelidade à herança antropocentrista do Renascimento, que fica evidente quando aloja o "transcendental" no sujeito, Kant recua do monopólio iluminista da razão ao escrever a Crítica da faculdade do juízo, sua Estética lato sensu, pois o juízo estético, baseado em sensações e sentimentos do prazer e do desprazer, não se deixa enquadrar em conceitos.

Curiosamente, tempo e espaço, os dois pilares do pequeno capítulo "Estética transcendental" da Crítica da razão pura, não determinam mais as reflexões da Crítica da faculdade do juízo, ou seja, elas serviram apenas como categorias básicas ("formas de intuição") da nossa percepção sensorial, considerada indispensável por Kant para o desenvolvimento de sua teoria do conhecimento, pois, apesar da independência postulada entre forma e conteúdo, os "pensamentos sem conteúdo são vazios; intuições sem conceitos são cegas."

\footnotetext{
${ }^{2}$ KANT. Crítica da razão pura, p. 62.

${ }^{3}$ KANT. Crítica da razão pura, p. 65.

${ }^{4}$ KANT. Crítica da razão pura, p. 62 (nota). Alexander Gottlieb Baumgarten (1714-1762) é considerado o fundador da Estética enquanto disciplina acadêmica.
}

${ }^{5}$ KANT. Crítica da razão pura, p. 89. 


\section{LESSING}

É curioso que Kant não faça nenhuma referência a Lessing e ao seu ensaio antológico Laocoonte, de 1766, publicado 15 anos antes da primeira edição da Crítica da razão pura, uma vez que este autor usou as categorias do tempo e do espaço para questionar, também, o autoritarismo das estéticas e poéticas racionalistas dos Kunstrichter, dos "juízes da arte", que criaram regras de como fazer uma obra de arte e de como escrever um bom poema. Além disso, recorrer às duas categorias para analisar as obras das diversas artes não era nenhuma novidade, pois tentativas semelhantes já se encontram em autores como Shaftesbury ou Diderot. Talvez Kant não tenha feito nenhuma referência a esses autores em sua Crítica da razão pura para deixar claro que, quando se trata de questões epistemológicas, não cabe falar em obras de arte.

O pivô das reflexões de Lessing é uma estátua da Antigüidade, encontrada em 1506, que mostra uma cena mitológica, descrita por Virgílio em sua Eneida, na qual o sacerdote troiano Laocoonte tenta salvar seus filhos de duas serpentes. Contestando o famoso veredicto de Horácio, Ut pictura poesis, que exige da criação poética que se atenha às regras da pintura e das artes plásticas em geral, Lessing procura mostrar que as regras da poesia são outras. Admitindo que suas reflexões são pouco sistemáticas, ele questiona os seguidores de Horácio, porque "Ora eles forçaram a poesia dentro dos confins estreitos da pintura; ora eles deixaram a pintura preencher toda a larga esfera da poesia." ${ }^{6}$ A falta de sistematicidade do ensaio aparece desde o prefácio, pois o nosso autor não distingue entre escultura e pintura quando se trata de estabelecer as diferenças em relação à poesia.

Além disso, Lessing se mostra bastante ambíguo no seu tratamento da tradição. Se ridiculariza, por um lado, um dos preceitos de Horácio, ele adota, com muita naturalidade, outro, a saber o do prodesse et delectare, que atribui à arte a função de "ser útil e agradar". $\mathrm{Ou}$ ainda quando explica que o artista plástico teve que abrandar o grito de dor de Laocoonte para que o seu rosto não ficasse desfigurado. Além de não aceitar qualquer estética do feio, Lessing evoca a Poética de Artistóteles quando exige que a dor de Laocoonte provoque compaixão e quando diz que qualquer excesso na expressão da dor impediria que essa compaixão surgisse no observador, pois causaria apenas desprazer. ${ }^{7}$

E Lessing se mostra mesmo herdeiro da estética clássica quando subentende qualquer atividade artística como imitação. Uma década antes do movimento do Sturm und Drang ("Tempestade e Ímpeto"), cuja "tempestuosidade" consistia, entre outras coisas, na rejeição da imitação e em sua substituição pela criação, Lessing insiste no princípio mimético:

Quando se diz que o artista imita o poeta, ou que o poeta imita o artista, isso pode significar duas coisas. Ou um deles faz da obra do outro o objeto efetivo da sua imitação, ou ambos possuem o mesmo objeto de imitação e um deles toma emprestado do outro o modo e a maneira de imitá-la. ${ }^{8}$

Se o dogma da mimese continua em vigor - ou é até enfatizado - dois mil anos após a Poética de Aristóteles, a análise da atividade artística de acordo com os critérios

\footnotetext{
${ }^{6}$ LESSING. Laocoonte, p. 76.

${ }^{7}$ LESSING. Laocoonte, p. 92.

${ }^{8}$ LESSING. Laocoonte, p. 137.
} 
do tempo e do espaço somente começa a ser feita de modo expressivo no século XVIII, que não apenas dá prosseguimento à entronização, inaugurada por Descartes, da razão como instância suprema, mas inicia também a emancipação dos sentidos - o que significa ao mesmo tempo um afastamento do pai do Racionalismo, para quem os sentidos eram, antes de mais nada, motivo de desconfiança. De Platão a Descartes, a ilusão de ótica servia de exemplo para mostrar que os sentidos, ao invés de contribuírem para o conhecimento da verdade, iludem o sujeito e esse conhecimento.

Cabe ressaltar, no entanto, que o resgate dos sentidos no século XVIII, cujo auge filosófico é o Sensualismo de Helvétius e d'Holbach, correu paralelamente à cisão cada vez mais acentuada entre ciência e arte. A desconfiança cartesiana em relação aos sentidos no intuito de se chegar a idéias "claras e distintas" não apenas fundamentou o desenvolvimento do pensamento científico ocidental, mas o distanciou ao mesmo tempo das artes, favorecendo a retirada destas para uma espécie de reservatório do belo onde a imprecisão da percepção sensorial não poderia causar "estragos”. Não precisa ser dito que, no decorrer desse processo de cisão, não se admitia que a obra de arte pudesse ter qualquer valor epistemológico, ou seja, gerar qualquer tipo de conhecimento.

De certa maneira, Kant resistiu à tendência de negar aos sentidos um valor epistemológico ou de confiná-los no âmbito da arte, quando, na "Estética transcendental", reservou um lugar ao tempo e ao espaço, mesmo se ambos são tratados apenas como as "formas de intuição" que permitem o registro da matéria através das sensações. Enquanto Kant procura garantir um lugar aos sentidos dentro de sua epistemologia, Lessing, de acordo com a mencionada cisão entre ciência e arte, se "retira" para o âmbito desta última quando recorre a espaço e tempo para falar das diferenças entre pintura (artes plásticas) e poesia (literatura):

Eu argumento assim. Se é verdade que a pintura utiliza nas suas imitações um meio ou signos totalmente diferentes dos da poesia; aquela, a saber, figuras e cores no espaço, já esta sons articulados no tempo; se indubitavelmente os signos devem ter uma relação conveniente com o significado: então signos ordenados um ao lado do outro também só podem expressar objetos que existam um ao lado do outro, ou cujas partes existem uma ao lado da outra, mas signos que se seguem um ao outro só podem expressar objetos que se seguem um ao outro ou cujas partes de seguem uma à outra. ${ }^{9}$

Aparentemente, Lessing defende uma mimese radical e estreita quando defende que a pintura, enquanto arte do espaço, deve imitar apenas corpos, e a poesia, enquanto arte do tempo, apenas ações. Uma vez que corpos não possuem início, meio e fim, sua "imitação" através da poesia parece ser inadequada, pois qualquer escrita tem um caráter linear e começa, obrigatoriamente, em um ponto para acabar em outro, não fazendo jus à simultaneidade do espaço e transformando-o, indevidamente, em sucessividade.

No entanto, o tom dogmático e pedante de Lessing engana, pois se trata, na verdade, mais de um raciocínio hipotético ("Eu argumento assim") do que da defesa de um ponto de vista. O próprio autor fala de duas saídas da suposta inadequação entre a imitação artística e o objeto imitado: Homero, ao descrever o escudo de Aquiles, teria evitado o

${ }^{9}$ LESSING. Laocoonte, p. 193. 
erro da "mania da descrição", ${ }^{10}$ que Lessing critica em seus contemporâneos, recorrendo ao artifício de descrever o processo de fabricação do escudo, ao invés do escudo acabado:

Homero, nomeadamente, pinta o escudo não como algo pronto, perfeito, mas antes como um escudo sendo feito. Portanto, ele lançou mão também aqui do enaltecido artifício de transformar o coexistente do seu objeto em consecutivo e fazer desse modo da pintura monótona de um corpo, a pintura vivaz de uma ação. ${ }^{11}$

Por mais que Lessing se mostre preso às doutrinas clássicas, é justamente nas reflexões sobre espaço e tempo que ele, no melhor espírito iluminista, se emancipa do autoritarismo da tradição. Partindo dos dois modos de percepção acessíveis à reflexão de qualquer pessoa, a saber a justaposição dos corpos e a sucessividade das ações, Lessing não apenas se afasta dos dogmas da tradição, mas também do risco de uma aplicação mecânica das categorias do tempo e do espaço à representação artística nos termos da adequação acima citada. Além de frisar, numa crítica ao academismo de Baumgarten, que os exemplos por ele escolhidos apresentam o "sabor da fonte", o exemplo que se tornou tema do ensaio, a estátua de Laocoonte, serve para mostrar que a separação rigorosa entre tempo e espaço de certa forma é superada nas obras-primas - ou então que o primor dessas obras se deve, entre outros elementos, à superação desse rigor.

Como a própria palavra diz, uma estátua, como qualquer obra "no espaço", é estática. À redundância dessa constatação corresponde uma outra, não menos trivial, de que qualquer acontecimento no tempo possui um caráter dinâmico. Ao contrário de Kant, Lessing não se limita a falar em tempo e espaço, mas "preenche" as duas "formas de intuição" com a matéria dos corpos e das ações:

Objetos que existem um ao lado do outro ou cujas partes existem uma ao lado da outra chamam-se corpos. Conseqüentemente são os corpos com as suas qualidades visíveis que constituem o objeto próprio da pintura.

Objetos que se seguem um ao outro ou cujas partes se seguem uma à outra chamam-se em geral ações. Conseqüentemente as ações constituem o objeto próprio da poesia. ${ }^{12}$

Ao invés de falar em “ações”, Lessing poderia ter falado simplesmente em movimentos dos próprios corpos, pois, assim que a relação estática entre os corpos muda, estes não apenas alteram sua distância no espaço, mas qualquer movimento ou mudança, qualquer dinamização dos corpos, possui um caráter temporal, pois diferencia entre um momento anterior e um momento posterior. Lessing pode ter privilegiado o termo "ação" porque tinha em mente a estátua de Laocoonte ao fazer suas considerações gerais. Mas, uma vez que ações costumam ser atribuídas a seres humanos, a preferência pelo termo pode ser vista, também, como reflexo da postura antropocêntrica do Iluminismo; ações são movimentos causados pelo ser humano.

Ainda no mesmo capítulo em que apresenta suas distinções um tanto áridas entre as artes do tempo e do espaço, Lessing passa a falar em formas híbridas da representação, que, aliás, não se enquadram mais nos moldes de uma mimese rigorosa. Lessing admite

\footnotetext{
${ }^{10}$ LESSING. Laocoonte, p. 76.

${ }^{11}$ LESSING. Laocoonte, p. 214.

${ }^{12}$ LESSING. Laocoonte, p. 193.
} 
que a pintura "imita" ações e a poesia, corpos, mesmo que seja recorrendo a determinados artifícios. No já mencionado exemplo do escudo de Aquiles, Homero teria recorrido ao processo de fabricação para falar desse escudo, que, conforme uma mimese rigorosa de um objeto estático, teria exigido uma representação simultânea.

O outro exemplo para uma representação híbrida é a própria estátua de Laocoonte, pois esta perde seu caráter estático pelo momento escolhido, um acontecimento extremamente agitado, a luta de Laocoonte contra as serpentes. O artista, de certo modo, "congelou" essa luta, tendo que optar por um momento que a reproduzisse da melhor maneira possível. Mas o caráter híbrido da obra não consiste apenas na "estatificação" do dinamismo da ação. Se, no caso da "dinamização" do escudo de Aquiles, o leitor pode acompanhar, passo a passo, o processo de sua fabricação, a estátua de Laocoonte exige do observador que ele acrescente, em sua imaginação, momentos anteriores e posteriores. Por isso, o escultor tem que escolher o momento mais "fecundo", pois "quanto mais nós olhamos, tanto mais devemos poder pensar além."13

Aparentemente, encontram-se aqui rudimentos de uma estética da recepção que rompe com uma visão rigorosamente mimética da atividade artística. Dito em termos iluministas: o receptor se emancipa do autoritarismo da obra, sendo que a própria obra, por ser "fecunda", favorece essa emancipação, sem ditar, necessariamente, o processo da recepção. Uma vez que o artista escolhe um determinado momento, ele, além de não se submeter ao autoritarismo de uma realidade a ser mimetizada, não prescreve ao receptor a "leitura" dessa obra.

As reflexões de Lessing, contudo, apesar de surgirem em pleno Iluminismo, impulsionadas por seu viés emancipador, não se desenvolvem na direção apontada e não chegam a valorizar a abertura deixada pelo momento fecundo. O espaço a ser preenchido não é visto como uma chance para o receptor se emancipar da autoridade da obra e seu criador, mas, ao contrário, como uma imposição que "nos obriga a meditações e conjecturas". ${ }^{14}$ Conseqüentemente, ele vê como uma das vantagens o poeta ter a

liberdade de se estender tanto sobre o passado quanto sobre o que se segue ao momento único da obra de arte, e, assim, a faculdade de não apenas nos mostrar o que a arte nos mostra mas também aquilo que ele pode apenas nos fazer adivinhar. ${ }^{15}$

O que Lessing vê como "liberdade de se estender", na verdade, representa uma limitação para a recepção, pois o leitor é obrigado a mimetizar um processo já mimetizado pelo poeta. O "apenas" do final da citação deixa claro que Lessing considera a escolha do momento fecundo mais como uma limitação da produção e da recepção da obra nas artes plásticas do que como uma chance para o observador.

\footnotetext{
${ }^{13}$ LESSING. Laocoonte, p. 99.

${ }^{14}$ LESSING. Laocoonte, p. 169.

${ }^{15}$ LESSING. Laocoonte, p. 222.
} 


\section{FOUCAULT}

Em Lessing, a libertação da poesia do domínio das artes plásticas pode ser vista como uma valorização da temporalidade em geral. A ideologia do progresso, que surge durante o Iluminismo, não apenas projeta determinadas utopias, mas faz parte de um pensamento que valoriza cada vez mais a própria idéia do desenvolvimento e da progressão como tal. Se a comparação entre o microcosmo da obra de arte, analisado por Lessing, e o macrocosmo histórico-cultural exige uma certa cautela para evitar a visão de uma simples relação de reflexo entre criação artística e ideologia vigente, ela parece se justificar pelos resultados da filosofia da história e da história cultural.

Em seu artigo sobre a temporalização no Fausto, Peter Matussek mostra como a obraprima de Goethe, em suas seis décadas de criação (aproximadamente de 1770 a 1832), "problematiza a mudança dramática, tanto no plano estético, quanto extra-estético, dos pontos de vista culturais do espaço em direção ao tempo, da naturalização da história à historização da natureza." ${ }^{16}$ Em boa parte, as mudanças na visão de mundo do Fausto são reflexo direto das pesquisas e reflexões científicas de Goethe, que, na última década do século XVIII, se volta contra as classificações inflexíveis de Lineu, que, segundo ele, não dão conta da diversificação e, principalmente, do caráter evolutivo e dinâmico da natureza.

Em As palavras e as coisas, Lineu serve como exemplo principal quando Foucault procura ilustrar a epistéme da idade clássica no âmbito da biologia. A oposição entre a visão estática das taxonomias de Lineu e os inícios de uma dinamização, como em Diderot, no final do século XVIII, mostra como nessa época aparecem os primeiros sinais de uma visão que privilegia o aspecto da transformação como algo inerente à natureza, ${ }^{17}$ para ceder, no início do século XIX, isto é, com a entrada na modernidade, a uma visão totalmente temporalizada:

E é nesse tempo classificado, nesse devir quadriculado e espacializado que os historiadores do século XIX se empenharão em escrever uma história enfim "verdadeira" - isto é, liberada da racionalidade clássica, de sua ordenação e de sua teodicéia, uma história restituída à violência irruptiva do tempo. ${ }^{18}$

Evidentemente, a temporalidade não "irrompe" apenas no século XIX. Ela é considerada na idade clássica, mas ela segue rigorosamente as coordenadas do "quadro" (tableau). A "Ordem das coisas", para usar o título que Foucault queria ter dado originalmente ao seu livro (e que foi mantido na tradução alemã), seguia um a priori espacial que punha estreitos limites a qualquer dinamismo e que possibilitava não apenas a transposição do herbário e suas classificações justapostas em taxonomias verbais, mas também a representação das estruturas simultâneas pelo "desdobramento linear da linguagem": ${ }^{19}$ "A Gramática Geral é o estudo da ordem verbal na sua relação com a simultaneidade que ela é encarregada de representar." 20

\footnotetext{
${ }^{16}$ MATUSSEK. Formen der Vezeitlichung, p. 1. Tradução nossa.

${ }^{17}$ Cf. FOUCAULT. As palavras e as coisas, p. 173.

${ }^{18}$ FOUCAULT. As palavras e as coisas, p. 180-181. Grifo nosso.

${ }^{19}$ FOUCAULT. As palavras e as coisas, p. 186.

${ }^{20}$ FOUCAULT. As palavras e as coisas, p. 115. Grifo de Foucault.
} 
As reflexões sobre a linguagem em As palavras e as coisas mostram não apenas que Foucault recorre à oposição entre tempo e espaço como paradigmas para analisar a passagem de uma idade clássica estática à modernidade dinâmica, mas que a mesma dicotomia, usada para o macrocosmo da história, serve para analisar o microcosmo da linguagem. Quando detecta na gramática e na biologia da idade clássica a mesma epistéme, Foucault procura evidenciar ao mesmo tempo que a macro-história natural de Lineu encontra seus paralelos no mundo micrológico da gramática. Por mais estranho que seja, para nós hoje, a idéia de uma história "espacial”, na idade clássica ela reencontra "uma de suas significações arcaicas": ${ }^{21}$

A idade clássica confere à história um sentido totalmente diferente: o de pousar pela primeira vez um olhar minucioso sobre as coisas [...]. Os documentos dessa história nova não são outras palavras, textos ou arquivos [como no Renascimento], mas espaços claros onde as coisas se justapõem: herbários, coleções, jardins; o lugar dessa história é um retângulo intemporal $[\ldots] .^{22}$

As referências arroladas por Foucault evidenciam que a oposição entre simultaneidade das idéias e o caráter sucessivo da linguagem era uma preocupação fundamental para os gramáticos da idade clássica:

Ela [a linguagem] não se opõe ao pensamento como o exterior ao interior, ou a expressão à reflexão [...]. Opõe-se, porém, a tudo isso, como o sucessivo ao contemporâneo [= simultâneo]. Ela está para o pensamento e para os signos como a álgebra para a geometria: substitui a comparação simultânea das partes (ou das grandezas) por uma ordem cujos graus se devem percorrer uns após os outros. É nesse sentido estrito que a linguagem é análise do pensamento: não simples repartição, mas instauração profunda da ordem no espaço. ${ }^{23}$

A idade clássica e a modernidade se diferenciam pela ordem que prevalece numa determinada epistéme, ou melhor: a epistéme é a ordem intermediária entre os códigos fundamentais e as teorias científicas que prevalecem numa determinada cultura e numa época. Diferentemente de Kant, Foucault não considera essa ordem como a forma com que o sujeito "ordena" a matéria, mas como derivado da epistéme, dessa "região mediana que libera a ordem no seu ser mesmo", sendo "ligada ao espaço ou constituída a cada instante pelo impulso do tempo". ${ }^{24}$

Foucault não tem como considerar a "ordem das coisas" como a priori subjetivo, pois a própria passagem da idade clássica para a modernidade é marcada pelo surgimento do sujeito, essa "invenção recente", ${ }^{25}$ que desestabilizou o "quadro" seguro das representações e é responsável pelo "profundo desnível da cultura ocidental". ${ }^{26}$ Uma vez que a ordem não é mais a representação assegurada do ser, mas resultado da síntese de um "sujeito

\footnotetext{
da temporalidade.

${ }^{22}$ FOUCAULT. As palavras e as coisas, p. 179. Grifo nosso.

${ }^{23}$ FOUCAULT. As palavras e as coisas, p. 114. Grifo de Foucault.

${ }^{24}$ FOUCAULT. As palavras e as coisas, p. XVII.

${ }^{25}$ FOUCAULT. As palavras e as coisas, p. 536.

${ }^{26}$ FOUCAULT. As palavras e as coisas, p. XXII.
}

${ }^{21}$ FOUCAULT. As palavras e as coisas, p. 179. O termo grego, istoria, realmente desconhecia o critério 
transcendental", que, de antemão, considera o ser, enquanto coisa em si, como algo inalcançável e irrepresentável, a crítica kantiana acaba com "o chão, o solo mudo onde os seres podem justapor-se": ${ }^{27}$

Em face da Ideologia [de Destutt de Tracy, que procura perpetuar o sistema da representação] a crítica kantiana marca, em contrapartida, o limiar de nossa modernidade; interroga a representação, não segundo o movimento indefinido que vai do elemento simples a todas as suas combinações possíveis, mas a partir de seus limites de direito. Sanciona assim, pela primeira vez, este acontecimento da cultura européia que é contemporâneo do fim do século XVIII: a retirada do saber e do pensamento para fora do espaço da representação. ${ }^{28}$

O "espaço da representação", de certa maneira, é um pleonasmo, pois pensar nos termos da representação é trabalhar com o paradigma espacial, onde as palavras se sobrepõem às coisas numa relação de correspondência ou analogia, isto é, numa relação que pertence ao âmbito estático do espaço. A "retirada do saber e do pensamento" desse espaço, ou então do espaço, leva à sua inserção no tempo através da projeção de finalidades e a invenção de origens. A introdução da função que Foucault apresentou como paradigma da modernidade significa ao mesmo tempo que a razão de ser das coisas se localiza fora delas, "fora" este que, na verdade, perde sua qualidade espacial e passa a ser reduzido a um ponto utópico, isto é, sem lugar definido, na linha do tempo.

$\mathrm{Na}$ "enciclopédia chinesa" de Borges, que, segundo Foucault, teria sido o ponto de partida do seu livro e que o fez "rir durante muito tempo", ${ }^{29}$ a classe mais cômica de animais, provavelmente, é aquela dos que "acabam de quebrar a bilha". ${ }^{30} \mathrm{O}$ efeito cômico é causado pela própria especificidade dessa “classe", que, por si só, levaria qualquer classificação nos moldes de Lineu ao absurdo. O elemento mais absurdo, no entanto, reside no elemento temporal: não se trata de animais que se caracterizam pelo hábito de quebrar bilhas - Foucault dedica um subcapítulo ao "caráter" quando fala em Lineu , hábito este que já seria suficientemente absurdo, mas que "acabam" de fazê-lo.

$\mathrm{Na}$ verdade, o maior absurdo de todos é a introdução da temporalidade, pois é incompatível com a natureza espacial do "quadro". O tempo, que confere uma "história" a um determinado ser, conduz a uma singularização que impossibilita sua inserção em qualquer taxonomia e suas denominações. O nome "estatifica" o ser e se o "quebradorde-bilha" já seria um ser bastante estranho, o fato de ele "acabar de quebrar a bilha", sua inserção no tempo, não tem mais como ser representado pelo nome, motivo pelo qual essa "classe" apenas pode ser circunscrita por uma paráfrase relativamente extensa.

\section{BENJAMIN}

A singularização, de certa maneira, é o pivô do antológico ensaio "A obra de arte na era de sua reprodutibilidade técnica", de Walter Benjamin, pois a "reprodutibilidade"

\footnotetext{
${ }^{27}$ FOUCAULT. As palavras e as coisas, p. XII.

${ }^{28}$ FOUCAULT. As palavras e as coisas, p. 334.

${ }^{29}$ FOUCAULT. As palavras e as coisas, p. XII.

${ }^{30}$ FOUCAULT. As palavras e as coisas, p. IX.
} 
do título visa justamente a sua superação. Também não há dúvida de que a singularidade da obra de arte tradicional e manualmente produzida e a decorrente formação de uma 'aura' em torno dela é resultado de um processo histórico durante o qual essa obra se tornou 'cada vez mais singular', ou seja: no decorrer do tempo, a simples singularidade numérica confere à obra uma posição de destaque.

Em princípio, a obra de arte tradicional - Benjamin privilegia as artes plásticas não passa por transformações materiais; ela é a mesma no passado e no presente. $O$ caráter estático de uma escultura sugere que se trata de um objeto que se mantém, em sua substância, inalterado durante séculos e até milênios. A degradação física, principalmente das pinturas, é um fato incontestável, mas os esforços de conservação e restauração evidenciam que há pelo menos o ideal da preservação e a proteção dos 'vestígios do tempo'. São os mesmos esforços que contribuem para a auratização da obra "como sendo aquele objeto, sempre igual e idêntico a si mesmo". ${ }^{31}$

Uma obra de arte, no entanto, não ganha sua posição de destaque simplesmente por ser "idêntica a si mesma", mas por ser idêntica no passado e no presente. A identidade de um objeto consigo mesmo somente deixa de ser um fato trivial quando este se afirma no tempo, resistindo às suas vicissitudes. Não se trata da afirmação da "mesmice", mas de uma relação, no mínimo, binária que se revela, no caso da história, pela igualdade entre dois planos temporais. O objeto é singular ("outro") por ser diferente dos objetos restantes; ele é o mesmo por ser igual em dois momentos diferentes.

Como os animais da enciclopédia chinesa-borgiana que "acabam de quebrar a bilha", a obra de arte escapa às classificações do "quadro"; ou, se não escapa, sempre as problematiza. Basta um único dado do passado, por mais banal que seja, para diferenciar ou singularizar um objeto qualquer no seu ambiente e tornar sua classificação questionável ou até impossível. Cada dado adicional do passado, portanto, torna esse objeto "cada vez mais único", qualificação esta cujo caráter paradoxal provém da incompatibilidade entre a perspectiva temporal e a espacial.

Se o rigor kantiano não permite que as categorias do tempo e do espaço se misturem, a região limítrofe entre elas foi o que mais estimulou as reflexões no âmbito da Estética. O "momento fecundo" de Lessing reside justamente na zona transitória entre o estáticoespacial e o dinâmico-temporal e a "aura" benjaminiana é o produto espacial de um "acúmulo do tempo". ${ }^{32}$ A barreira que a aura representa em termos sociológicos, impedindo a apropriação lato sensu da obra de arte pela sociedade (no "espaço social"), é resultado de um culto que, por definição, se alimenta de uma atitude repetitiva. O culto não se caracteriza apenas pela devoção em torno do mesmo objeto, mas também pela repetição "idêntica" deste ritual do passado no presente.

Se Benjamin acerta no diagnóstico, a solução proposta é, no mínimo, problemática. Como tentamos mostrar numa análise sucinta, ${ }^{33}$ o próprio conceito de "reprodução", que

\footnotetext{
${ }^{31}$ BENJAMIN. Obras escolhidas, p. 167.

${ }^{32}$ O termo "arqueologia", do subtítulo do livro de Foucault, que será retomado no livro posterior, A arqueologia do saber, também aponta para uma zona de transição entre tempo e espaço, uma vez que a sobreposição das camadas espaciais resulta de um processo temporal. Cf. também a "sobreposição de camadas finas e translúcidas" que Benjamin toma emprestado em Valéry (BENJAMIN. Obras escolhidas, p. 206). ${ }^{3}$ OTTE. A reprodutibilidade técnica da obra cinematográfica - representação ou clonagem?
} 
está por trás da "reprodutibilidade", possui pelo menos dois sentidos diferentes: a gravação técnica - sonora ou ótica - de uma obra de arte e a multiplicação desta gravação em um número teoricamente infinito de exemplares. Benjamin não diferencia, como Lessing, entre a simultaneidade das artes visuais e o caráter sucessivo da música, diferença esta que o teria levado a identificar mais um tipo de reprodução, que é a interpretação de uma composição por um músico.

Sabemos também que a multiplicação de uma obra de arte tecnicamente reprodutível não impediu que ela ganhasse uma aura, o que se torna explícito no uso de expressões como "cinema cult". Uma foto ou um filme não deixam de ser singulares por serem tecnicamente reprodutíveis. O "olhar" inusitado do fotógrafo, os meios técnicos de manipulação, como, por exemplo, a simples troca da objetiva e, no caso do cinema, a própria seqüência de imagens, singularizam também as obras tecnicamente produzidas - trata-se de produções, e não de simples reproduções no sentido de uma mimese fiel da realidade.

A própria passagem do objeto reproduzido para a sua reprodução envolve aspectos temporais - a reprodução é sempre posterior ao objeto reproduzido, envolvendo algum tipo de alteração, seja ela condicionada pelas propriedades técnicas do aparelho, seja por uma intervenção direta da "mão" do fotógrafo, sem falar da montagem de um filme. No caso do cinema, a temporalidade fica mais evidente ainda quando se pensa na seqüencialidade do filme como tal e na sua manipulação no momento da montagem. Benjamin, entretanto, não analisa o caráter sucessivo do filme e se limita a falar do "efeito de choque de suas seqüências de imagens". ${ }^{34}$

A destruição da aura por meio da reprodutibilidade técnica não acontece, porque a multiplicação da obra e sua decorrente identidade no espaço não anula sua singularidade e sua identidade baseada em fatores temporais, seja no interior da obra, seja pelo seu percurso histórico e social. Apesar da abordagem marxista anunciada no primeiro capítulo do ensaio, que tornaria considerações históricas e sociais indispensáveis, Benjamin se limita a comentários genéricos sobre a tradição e sobre o comportamento humano numa perspectiva antropológica, quando, por exemplo, constata que a obra de arte é objeto de um culto ou quando vê no cinema o confronto do homem com o "aparelho".

A aura e o culto gerado por ela resultam de uma presença física - a obra em sua materialidade -, presença esta que aponta para uma ausência preenchida por mistificações, muitas vezes projetadas no passado. Parece que é o próprio caráter estático de uma obra que gera a 'aura de mistério' em torno do objeto, e que se transforma, no decorrer do tempo, em um testemunho mudo de épocas passadas e desconhecidas. Benjamin, porém, descarta uma solução 'iluminista' para combater "a autoridade da coisa". ${ }^{35}$ A emancipação, para ele, não consiste mais numa atitude libertadora do sujeito, muito menos mediante a aquisição de conhecimentos, mas são as próprias "obras de arte [que] se emancipam do seu uso ritual" 36 - através da reprodutibilidade técnica.

A própria história do cinema mostrou que combater o tempo (a tradição) com as armas do espaço (via reprodutibilidade) acaba sendo uma luta quixotesca, pois, por mais que

\footnotetext{
${ }^{34}$ BENJAMIN. Obras escolhidas, p. 194.

${ }^{35}$ BENJAMIN. Obras escolhidas, p. 168.

${ }^{36}$ BENJAMIN. Obras escolhidas, p. 173. Grifo de Benjamin.
} 
se reproduza uma obra, ela não escapa dos efeitos do tempo e a correspondente mistificação ou auratização que se reflete no isolamento físico-espacial da obra. De certa maneira, Benjamin supera esse impasse em suas teses intituladas "Sobre o conceito da história", que, evidentemente, não têm como não levar em conta a questão da temporalidade, considerando a questão do espaço, sem optar por uma solução puramente espacial. Agora sim, o espaço se revela como uma arma eficiente contra o conceito predominante de temporalidade (sem monopolizá-lo) e contra a temporalização do pensamento ocidental, cujos primeiros sinais podem ser detectados em Lessing e seus contemporâneos europeus, e que chega ao seu auge, como vimos em Foucault, no século XIX.

A crítica ao positivismo e à socialdemocracia, que Benjamin vê como os representantes intelectuais e políticos do pensamento progressista, na verdade é apenas a superfície de um questionamento maior que visa a mentalidade temporalizada como um todo. As catástrofes do século XX, que Benjamin aponta como conseqüência da temporalização, não resultaram apenas de políticas equivocadas, mas derivam do próprio pensamento temporalizado. Na tese central sobre o "anjo da história", fica evidente que, para Benjamin, a verdadeira catástrofe está na "nossa" visão do tempo:

Onde nós vemos uma cadeia de acontecimentos, ele vê uma catástrofe única, que acumula incansavelmente ruína sobre ruína e as dispersa a nossos pés. Ele gostaria de deter-se para acordar os mortos e juntar os fragmentos. Mas uma tempestade sopra do paraíso e prendese em suas asas com tanta força que ele não pode mais fechá-las. ${ }^{37}$

O problema, portanto, não é apenas a idéia do progresso, mas a própria progressão, o continuum que Benjamin não se cansa de responsabilizar - em cada uma das teses 14, 15 e 16 - pela catástrofe política e mental do seu tempo. Conseqüentemente, combater, "fazer explodir" 38 esse continuum é o alvo em que as energias revolucionárias devem se concentrar. $\mathrm{O}$ episódio emblemático para esse postulado aconteceu na Revolução de julho em Paris, quando os combatentes atiraram contra os relógios "pour arrêter le jour", 39 para parar o tempo. Se o primeiro passo é destrutivo no sentido de interromper o fluxo do tempo linear, o segundo já é construtivo por possibilitar a "redenção" do passado do seu esquecimento. A progressão enquanto ideologia não peca apenas pela "pobreza" conceitual, pois o pensamento linear é por natureza unidimensional, mas a "catástrofe" detectada por Benjamin consiste principalmente no distanciamento entre presente e passado. Parar o tempo, portanto, é apenas o primeiro passo para acabar com a nossa visão "pobre" da realidade e para possibilitar uma visão pluridimensional ou multifacetada, que se dá no espaço:

[...] a historiografia marxista tem em sua base um princípio construtivo. Pensar não inclui apenas o movimento das idéias, mas também sua imobilização. Quando o pensamento pára, bruscamente, numa configuração saturada de tensões, ele lhes comunica um choque, através do qual essa configuração se cristaliza enquanto mônada. ${ }^{40}$

\footnotetext{
${ }^{37}$ BENJAMIN. Obras escolhidas, p. 226.

${ }^{38}$ BENJAMIN. Obras escolhidas, p. 230.

${ }^{39}$ BENJAMIN. Obras escolhidas, p. 230.

${ }^{40}$ BENJAMIN. Obras escolhidas, p. 231. Grifo nosso.
} 
Curiosamente, o ato revolucionário, normalmente associado a uma situação de extrema agitação, consiste, para Benjamin, numa imobilização; o dinamismo inerente à própria palavra "revolução" cede o lugar à cristalização, ao enrijecimento, representado na figura espacial da mônada. Cabe ressaltar ainda que essa revolução não se restringe a atos violentos nas ruas, mas se estende também aos choques - não menos violentos produzidos pelo "pensamento" que não parece ter dono.

A "explosão" do continuum destrói o conceito linear para permitir a construção de um outro conceito que Benjamin não denomina, nem define, mas que é visualizado através de metáforas espaciais. Introduzindo outro conceito fundamental para a compreensão dessa outra visão da história, a citação, ${ }^{41}$ Benjamin ilustra a mesma mediante um "salto de tigre":

A Revolução Francesa se via como uma Roma ressurreta. Ela citava a Roma antiga como a moda cita um vestuário antigo. A moda tem um faro para o atual, onde quer que ele esteja na folhagem do antigamente. Ela é um salto de tigre em direção ao passado. Somente, ele se dá numa arena comandada pela classe dominante. O mesmo salto, sob o livre céu da história, é o salto dialético da Revolução, como o concebeu Marx. ${ }^{42}$

As metáforas da "arena" e do "céu da história" (que também aparece na tese 4) apontam para espaços nos quais a história se passa e que servem ao mesmo tempo como palco onde o "encontro secreto, marcado entre as gerações precedentes e a nossa" 43 pode acontecer. A "presença do passado no presente", da qual nos fala Jeanne Marie Gagnebin no prefácio das Obras escolhidas de Benjamin, ${ }^{44}$ só é possível quando a história se passa no mesmo espaço, na mesma "arena".

O espaço benjaminiano, no entanto, não é simplesmente uma "forma de intuição" metaforizada ou estetizada que serve apenas como ambiente externo para os acontecimentos. A espacialização do tempo não se limita a considerações sobre a história, ela perpassa a obra benjaminiana não apenas enquanto repertório metafórico, mas envolve sua própria escrita. Benjamin não chega a postular a "explosão do continuum" textual, mas suas explanações em torno do tratado medieval e do ensaio no "Prefácio epistemológico" de Origem do drama barroco alemão ${ }^{45}$ não deixam dúvida de que a luta tanto contra pensamentos quanto procedimentos lineares foi uma das preocupações principais em todas as fases de sua produção. $O$ próprio texto benjaminiano é um mosaico que, enquanto formação imagética, foge à unidimensionalidade da progressão textual, possibilitando assim que suas partes, fragmentos ou não, se relacionem e se citem constantemente:

Incansável, o pensamento começa sempre de novo, e volta sempre, minuciosamente, às próprias coisas. Esse fôlego infatigável é a mais autêntica forma de ser da contemplação. Pois ao considerar um mesmo objeto nos vários estratos de sua significação, ela recebe ao mesmo tempo um estímulo para o recomeço perpétuo e uma justificação para a intermitência do seu ritmo. Ela não teme, nessas interrupções, perder sua energia, assim como o mosaico, na fragmentação caprichosa de suas partículas, não perde sua majestade. ${ }^{46}$

\footnotetext{
${ }^{41}$ Cf. OTTE. A reprodutibilidade técnica da obra cinematográfica - representação ou clonagem?

${ }^{42}$ BENJAMIN. Obras escolhidas, p. 230.

${ }^{43}$ BENJAMIN. Obras escolhidas, p. 223.

${ }^{44}$ BENJAMIN. Obras escolhidas, p. 15.

${ }^{45}$ BENJAMIN. Origem do drama barroco alemão, p. 49 ss.

${ }^{46}$ BENJAMIN. Origem do drama barroco alemão, p. 50-51.
} 
Benjamin, muitas vezes apresentado como um dos maiores pensadores da modernidade, marca ao mesmo tempo o fim desta modernidade em sua acepção foucaultiana. Como foi exposto acima, Foucault considera a temporalização da epistéme como um dos aspectos decisivos na passagem da idade clássica para a modernidade. Se Foucault vê no estruturalismo de Saussure sinais de uma 'volta ao espaço' - o próprio termo "estrutura" aponta para essa volta -, as teses de Benjamin e sua espacialização da história representam outro passo na mesma direção, sendo que Benjamin não sacrifica a história - ou a visão diacrônica - como aconteceu em alguns representantes estruturalistas. ${ }^{47}$ Muito pelo contrário: "cada fato histórico apresentado dialeticamente se polariza, tornandose um campo de forças no qual se processa o confronto entre sua história anterior e sua história posterior." ${ }^{48} \mathrm{O}$ campo de forças é um espaço, mas seus pólos se situam no tempo.

\section{A B STRACT}

This article aims to show that time and space are not only basic a prioris for the perception of objects (Kant), but that these two categories have a distinct value in the epistéme (Foucault), that is, historical a prioris of every period. Our hypothesis is that the temporalization of thinking, which characterizes the passage from the Classical to the Modern Age, encounters in Walter Benjamin one of its most expressive opponent by focusing space.

\section{KEYWORDS}

Space. Aesthetics. History. Walter Benjamin.

\section{REFERÊNCIAS}

BENJAMIN, Walter. A obra de arte na era de sua reprodutibilidade técnica. In:

Obras escolhidas. Magia e técnica, arte e política. Trad. Paulo Sérgio Rouanet. São Paulo: Brasiliense, 1985. p. 165-196.

BENJAMIN, Walter. Das Kunstwerk im Zeitalter seiner technischen Reproduzierbarkeit. In: . Gesammelte Schriften. Vol. I/2. Frankfurt/M.: Suhrkamp, 1990. p. 431-470.

BENJAMIN, Walter. Origem do drama barroco alemão. Trad. Sérgio Paulo Rouanet. São Paulo: Brasiliense, 1984.

BENJAMIN, Walter. Passagens. Organização Willi Bolle; colaboração na organização Olgária Chain Féres Matos; tradução do alemão Irene Aron; tradução do francês Cleonice Paes Barreto Mourão. Belo Horizonte: Editora UFMG; São Paulo: Imprensa Oficial do Estado de São Paulo, 2006.

\footnotetext{
${ }^{47}$ Para François Dosse, autor de História do estruturalismo, o declínio do movimento se deve ao banimento tanto do sujeito quanto da historicidade. Cf. KRAUSZ. O "enterro" do estruturalismo, p. 11.

${ }^{48}$ BENJAMIN. Passagens, p. 512.
} 
FOUCAULT, Michel. As palavras e as coisas: uma arqueologia das ciências humanas. Trad. Salma Tannus Muchail. São Paulo: Martins Fontes, 2002.

FOUCAUlT, Michel. Die Ordnung der Dinge. Frankfurt: Suhrkamp, 2002.

FOUCAULT, Michel. Les mots et les choses: une archéologie des sciences humaines. Paris: Éditions Gallimard, 1966.

KANT, Immanuel. Crítica da razão pura. Trad. Manuela Pinto dos Santos, Alexandre Fradique Morujão. Introdução e notas Alexandre Fradique Morujão. 2. ed. Lisboa: Fundação Gulbenkian, 1989.

KANT, Immanuel. Werke. Vol. III. Darmstadt: Wissenschaftliche Buchgesellschaft, 1975. KRAUSZ, Luis. O 'enterro' do estruturalismo. François Dosse historia o movimento na França. Folha de S. Paulo, São Paulo, 26 dez. 1993. Caderno Mais, p. 11.

LESSING, Gotthold Ephraim. Laocoonte: ou sobre as fronteiras da pintura e da poesia. Introdução, tradução e notas Márcio Seligmann-Silva. São Paulo: Iluminuras, 1998.

LESSING, Gotthold Ephraim. Laokoon: oder über die Grenzen der Malerei und Poesie. Mit einem Nachwort von Ingrid Kreuzer. Stuttgart: Reclam, 1987.

MATUSSEK, Peter. Formen der Vezeitlichung. Der Wandel des Faustschen Naturbildes und seine historischen Hintergründe. In: . Goethe und die Verzeitlichung der Natur. München, 1998. p. 202-233. Também disponível no site http://134.99.68.195/ admin/ Pub/A_17.pdf.

OTTE, Georg. A reprodutibilidade técnica da obra cinematográfica - representação ou clonagem? Uma análise crítica de um conceito básico de Walter Benjamin. Aletria, Belo Horizonte, Faculdade de Letras da UFMG, v. 8, p. 287-300, 2001. 